\title{
Activation of Teliospore Germination in Uromyces appendiculatus var. appendiculatus ${ }^{1}$ )
}

\author{
II. Light and Host Volatiles
}

\author{
By \\ R. E. Gold and K. Mendgen²)
}

With 6 figures

Received April 29, 1983

\begin{abstract}
.
The effects of light and host volatiles on teliospore germination in Uromyces appendiculatus var. appendiculatus were studied.

1. Light intensities ranging 15-26000 lux supported teliospore germination and basidiospore formation. The optimum light intensity was 17000 lux under the described conditions. Light-dark alternation was necessary for teliospore germination: no germination occurred under continuous light or continuous dark conditions. The process of teliospore germination, basidiospore formation, and basidiospore release followed a synchronous, rhythmic pattern of development. Teliospore germination was triggered by the phase change light $\rightarrow$ dark (i.e. "light off"). Under long-day conditions basidiospore release exhibited a nocturnal periodicity with peak maxima occurring $\sim 7 \mathrm{~h}$ after light was turned off.

2. Fifteen days after a $10 \mathrm{~d}$ exposure to host volatiles, $70-80 \%$ of the treated spores germinated; minor increases in spore mortality were observed. Inoculations made with seedling-treated teliospores resulted in heavy pycnial infections.

3. The heat and seedling activation methods developed for teliospores of bean rust proved ineffective when applied to dormant teliospores from six other unrelated rust species.

1) This study represents a portion of a dissertation submitted by the senior author to the Faculty of Biology at the University of Konstanz (Fed. Rep. Germany) in March, 1983, in partial fulfillment of the requirements for the degree of Doctor of Natural Sciences (Dr. rer. nat.).

2) Author to whom reprint requests should be addressed.
\end{abstract}




\section{Zusammenfassung \\ Die Aktivierung der Teleutosporenkeimung \\ bei Uromyces appendiculatus var. appendicalatus durch Licht und flüchtige Substanzen aus Bohnen}

Die Aktivierung der Teleutosporenkeimung bei Uromyces appendiculatus var. appendiculatus durch Licht, Lichtrhythmen und flüchtige Substanzen aus Bohnenkeimlingen wurde untersucht.

1. Gute Teleutosporenkeimung wurde bei 17000 lux beobachtet. Ein Licht-DunkelWechsel war für den Keimprozeß notwendig; unter Dauerlicht- oder Dauerdunkelbedingungen fand keine Keimung statt. Teleutosporenkeimung, Basidiosporenausbildung und -abschleuderung verliefen in strenger Gesetzmäßigkeit. Das auslösende Signal für die Keimung war der Beginn der Dunkelperiode (d.h. der Phasenwechsel von Licht $\rightarrow$ Dunkel), wobei die maximale Basidiosporenabschleuderung $\sim 7 \mathrm{~h}$ nach dem Ausschalten des Lichtes stattfand. Unter LangTag-Bedingungen wies die Abschleuderung der Basidiosporen eine nocturnale Periodik auf.

2. Fünfzehn Tage nach einer 10tägigen Behandlung mit flüchtigen Substanzen aus keimenden Bohnensamen waren $70-80 \%$ der behandelten Teleutosporen ausgekeimt. Inokulationen mit Basidiosporen von behandelten Teleutosporen führten zu hohen Infektionsraten.

3. Die Behandlung mit Wärme und Bohnenkeimlingen hatte auf ruhende Teleutosporen von sechs anderen Rostpilzarten keinen signifikanten Einfluß auf ihre Keimung.

Fresh teliospores of bean rust (Uromyces appendiculatus var. appendiculatus) are dormant (see MendGen 1983). Teliospore dormancy in bean rust may be broken by an indoor or outdoor storage period or by a heat treatment (Gold and MENDGEN $1983 \mathrm{a}$ ). Activation of teliospore germination by exposure to host substances (KLISIE wiCz 1972, 1973) or light (Neuhaus 1969, Pady and Cramer 1971, Sibilia 1931) has been reported for Gymnosporangium and Puccinia species. In the present study, the effects of light and host volatiles on the activation and pattern of teliospore germination in $U$. appendiculatus var. appendiculatus are reported.

\section{Materials and Methods}

\section{Fungal isolates and host plants}

The rust isolates and host plants studied were described in the first part of this study (Gold and MendGen 1983a). The results were analysed using Wilcoxon's rank test (Figs. 5,6 ) or linear regression (Fig. 2a).

\section{Influence of light on teliospore germination}

\subsection{Light intensity}

Refrigerator-stored teliospores of SWBR were spread onto water agar plates, with minimal exposure to yellow/orange safe light. Using various phatometrically defined gray filters the following light intensities were established for incubation of the spores: $0,15,35$, $70,150,350,675,1350,2100,3400,6800,9600,13500,17000$, and $26000 \mathrm{~lx}$. Teliospores were scored for percentage germination and mortality after 7 and/or $15 \mathrm{~d}$ incubation at $18{ }^{\circ} \mathrm{C}$ under a $16 \mathrm{~h}$ phatoperiod.

\subsection{Photoperiod}

Teliospores of SWBR which had been stored at $4{ }^{\circ} \mathrm{C}$ for $\sim 40$ mo were used to study the rhythmic germination process. In some experiments, heat- or seedling-treated spores were tested for comparison. The spores were incubated at $18^{\circ} \mathrm{C}$ under $1000 \mathrm{~lx}(16 \mathrm{~h} / \mathrm{d})$ as described 
earlier (Gold and MENDGen 1983a). After $4 \mathrm{~d}$ of incubation, the microscopical observations of percentage germination and mortality began. Separate spore lots were scored at 08.00 and $22.00 \mathrm{~h}$ on the fourth day and at $00.00,01.00,02.00,03.00,04.00,05.00,06.00$, and $08.00 \mathrm{~h}$ on the fifth day of incubation. Precautions were taken to avoid exposing the spores to light between 22.00 and $06.00 \mathrm{~h}$.

The effect of various photoperiods on basidiospore release was determined using a modified 24 h hygrothermograph according to methods described by BEGA (1959). T'eliospores were applied as $1 \mathrm{~mm}$ wide and $\sim 2-3 \mathrm{~cm}$ long line onto a Sartorius filter on agar and fixed over the rotating drum of the hygrathermograph. The space between the line of spores and the agar surface in a Petri dish attached to the drum was adjusted to $1-2 \mathrm{~mm}$; this small distance insured that $100 \% \mathrm{RH}$ was maintained in the Petri dish and minimized the lateral cast of basidiospores. The entire apparatus was incubated in a lighttight chamber at $18 \pm 1.0^{\circ} \mathrm{C}$ under $1000 \mathrm{~lx}$. The photoperiod was controlled by a switch clock. The plates were exchanged daily and basidiospores on the agar surface were fixed and stained immediately after removal with a fine mist of $2 \%$ acid fuchsin in a chloral hydrate-ethanol solution. Half-hourly or hourly spore counts with an accuracy of \pm 5 min were made possible by counting basidiospores along the length of predetermined increments at $\times 125$ (bright field optics) in a microscope. The formation of secondary basidiospores was only rarely observed on the agar surface.

The active period of basidiospore release from teliospores incubated under a long-day photoperiod was investigated in vivo using time course host infection studies.

\section{Influence of host volatiles on teliospore germination}

Ten grams of bean seeds (dry weight) per treatment were first washed for $1-2 \mathrm{~h}$ in cold running tap water. The seeds were then drained and transferred to a plastic Petri dish bottom lined with filter paper. Ten $\mathrm{ml}$ of tap water were added and a miniaturized incubation chamber was formed by inverting a second bottom containing the teliospores on agar onto the first and sealing with adhesive tape. Figure 1 illustrates the chamber construction used throughout all experiments. Seeds of the bean cultivars 017, Golden Gate Wax, and Favorit were tested.

Fig. 1. Diagrammatic representation of seedling treatment chamber

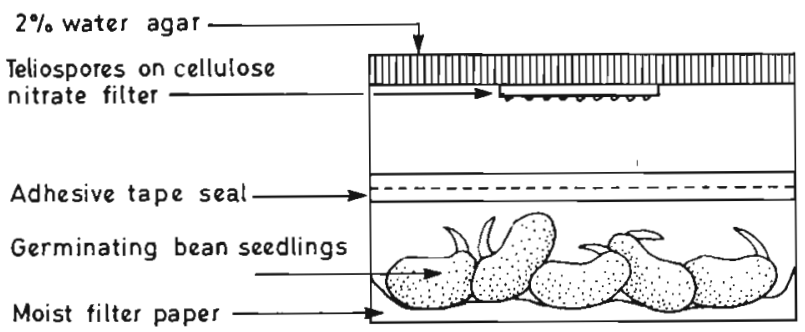

Following assembly, the chambers were incubated at $18 \pm 0.5^{\circ} \mathrm{C}$ under $1000 \mathrm{~lx}(16 \mathrm{~h} / \mathrm{d})$. Two days after beginning of the treatment, the fully imbibed seeds had already absorbed the original $10 \mathrm{ml}$ of water and had begun to germinate. The chambers were opened every $2 \mathrm{~d}$ for $3-5 \mathrm{~min}$ in order to rinse the developing seedlings thoroughly in running tap water and to aerate the teliospores. The chambers were then carefully resealed and returned to incubation conditions. At $10 \mathrm{~d}$ the seeds were removed and the spores were incubated further with normal unsealed lids.

A series of experiments using the standard seedling treatment were conducted; unless otherwise noted, teliospores of SWBR and seeds of Golden Gate Wax were used. The influence of (1) spore age (fresh versus refrigerator-stored spores) on percentage germination and mortality, (2) spore isolate (SWBR versus GBR, RBR 1, KBR 1) on percentage germination, (3) dark incubation on percentage germination and mortality, and (4) the length of seedling treatment on percentage germination and mortality was determined. In the latter set of experiments, seeds of 017 were initially surface sterilized ( $3 \mathrm{~min}$ in $1 \%$ sodium hypochloride) and then incubated in sealed Petri dishes without rinse or aeration breaks for either 0 (control), $4,8,10,12,16$, or $20 \mathrm{~d}$. Microscopical evaluations of percentage germination and mortality 
were made up to $20 \mathrm{~d}$ after each respective treatment and the controls. The infectivity of basidiospores produced by seedling treated teliospores was tested as described earlier (GOLD and Mendgen 1983a).

\section{Influence of heat and seedling treatments on teliospore germination of selected rust species}

Several rusts (see Gold and Mengden 1983a) with constitutionally dormant teliospores were tested. The heat treatment was conducted at $32 \pm 0.1^{\circ} \mathrm{C}$ for $4 \mathrm{~d}$ and the seedling trearment for $10 \mathrm{~d}$ using seeds of Golden Gate Wax. The treatments were carried out as described for the bean rust isolates. A minimum of 2 experiments per treatment were conducted for each rust. Microscopical evaluations were made at $15 \mathrm{~d}$ after each respective treatment or plating out of the controls.

\section{Results}

\section{Influence of light on teliospore germination}

Fifteen $1 \mathrm{x}(16 \mathrm{~h} / \mathrm{d})$ were sufficient for teliospore germination and development of basidiospores (Fig. 2 a). Light intensities ranging from 15$17000 \mathrm{~lx}$ caused a gradual increase in germination $(r=0.95, \mathrm{P}<0.05)$. At $26000 \mathrm{~lx}$ a small inhibition of germination was observed. Spore mortality was not significantly influenced by incubation in darkness or under light up to $26000 \mathrm{~lx}(\mathrm{r}=0.16, \mathrm{P}>0.05)$.

The density of teliospores incubated on agar had, in all experiments reported above, no significant influence on the rate of germination or mortality. Spore densities up to $900 / \mathrm{mm}^{2}$ ( $=$ dark brown layer) were tested.

Teliospore germination began $3-5 \mathrm{~d}$ after rehydration (= plating out of the spores on water agar) when the spores were incubated at $18^{\circ} \mathrm{C}$ under $1000 \mathrm{~lx}(16 \mathrm{~h} / \mathrm{d})$. A typical time-course of the germination process (see Gold and MENDGen 1983 b) is shown graphically and schematically in Figure 2 b. In this experiment trace amounts of development occurred during the third night of incubation, giving rise to $\sim 3 \%$ germination. Dúring the course of the fourth day no new germination (i. e. spores with newly developing metabasidia) developed until the time between 22.00 and $00.00 \mathrm{~h}$. The greatest increase in new germination occurred between 00.00 and $01.00 \mathrm{~h}$. Thereafter, the level increased slightly until $\sim 06.00 \mathrm{~h}$. The formation and release of basidiospores was predominant in the period between 01.00 and $08.00 \mathrm{~h}$.

When subjected to alternating $16 \mathrm{~h}$ light and $8 \mathrm{~h}$ dark ( $=$ long-day photoperiod), with temperature $\left(18^{\circ} \mathrm{C}\right)$ and $\mathrm{RH}(100 \%)$ held constant, teliospore germination and basidiospore release occurred rhythmically with a nocturnal periodicity of $\sim 24$ h (Fig. 3 a). During the fourth dark period basidiospore release began $5-6 \mathrm{~h}$ after the light was off, sharply rose to a peak at $04.00-06.00 \mathrm{~h}$, then declined equally sharp to reach the zero level soon after the light had switched on. Similar but progressively smaller peak maxima occurred in the dark during the following days after which spore release fell to a minimum (Figs. 3, 4). The same nocturnal periodicity was maintained when spores were subjected to a short-day or ultra short-day photoperiod (Figs. $3 \mathrm{~b}-\mathrm{c}$ ). In the latter case the maximum peak occured $1 \mathrm{~d}$ later and arose 
during the fifth dark period. The teliospores required a minimum of $3-4 \mathrm{~h}$ darkness dark for normal teliospore germination and basidiospore release; a daily exposure to $1000 \mathrm{~lx}$ for $0.5 \mathrm{~h}$ was sufficient for the germination process (Fig. 3 c).
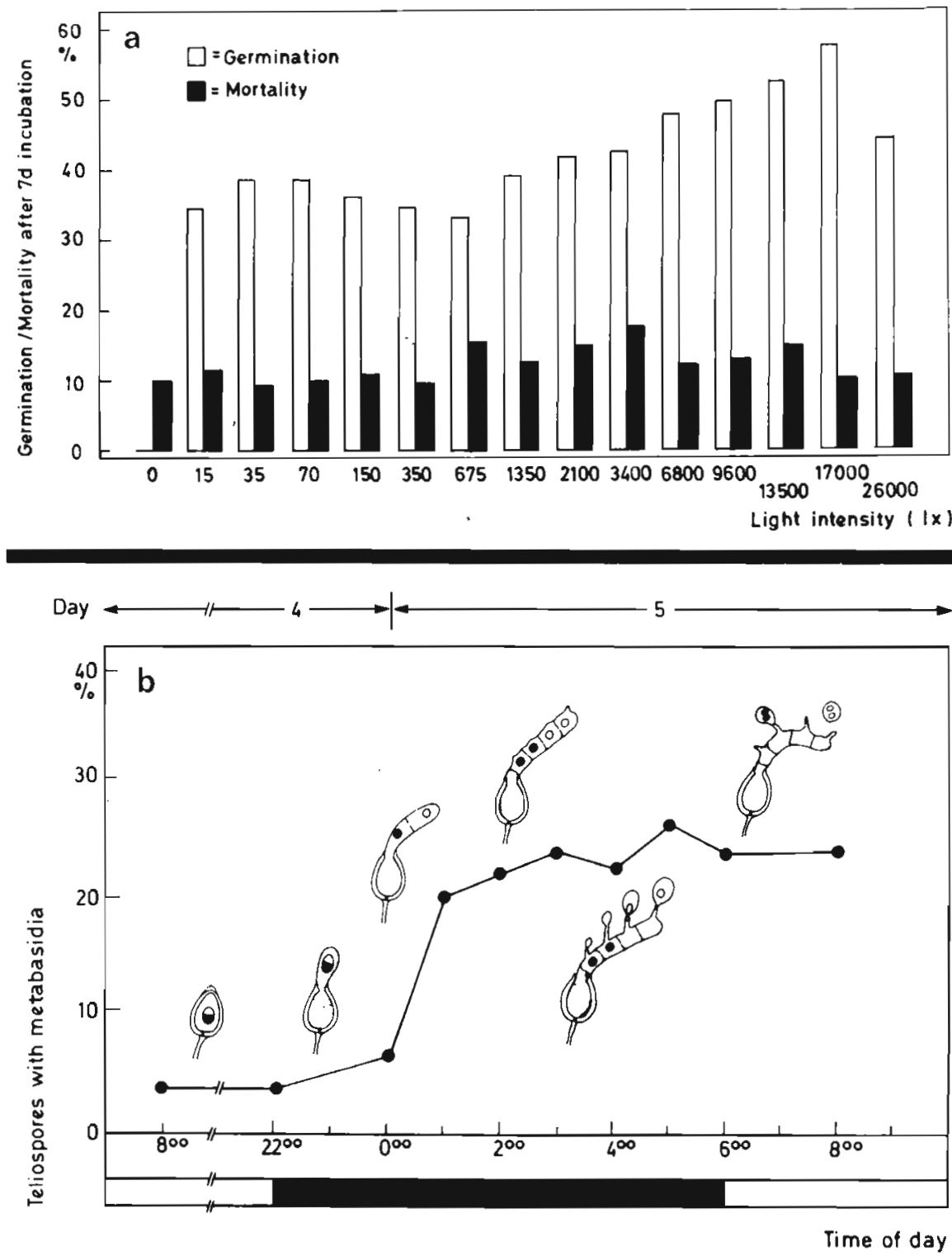

Fig. 2. (a) Effect of light intensity on teliospore germination and mortality of SWBR. Spores were incubated under various intensities ranging from $0-26000 \mathrm{~lx}$ ( $16 \mathrm{~h}$ photoperiod). Spore age: $34 \mathrm{mo}$; (b) Time course of teliospore germination after $4 \mathrm{~d}$ of incubation. The drawings chronologically represent characteristic stages of spore germination. Spore age: 

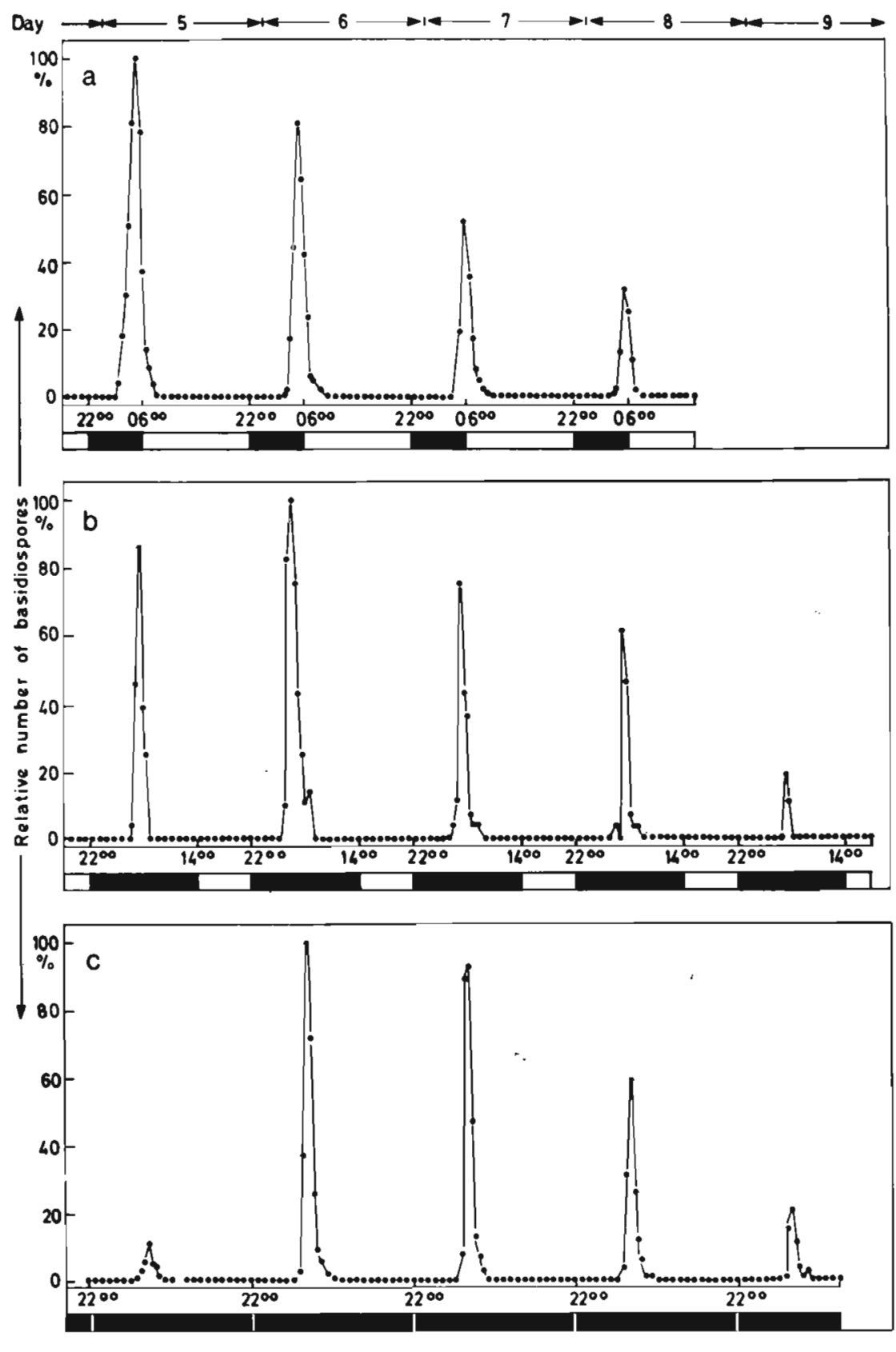

Time of day

Fig. 3. Effect of the length of photoperiod on basidiospore release. Teliospores of SWBR were incubated throughout each experiment under (a) long-day, (b) short-day, or (c) ultra shortday conditions. Spore age: 35 mo 

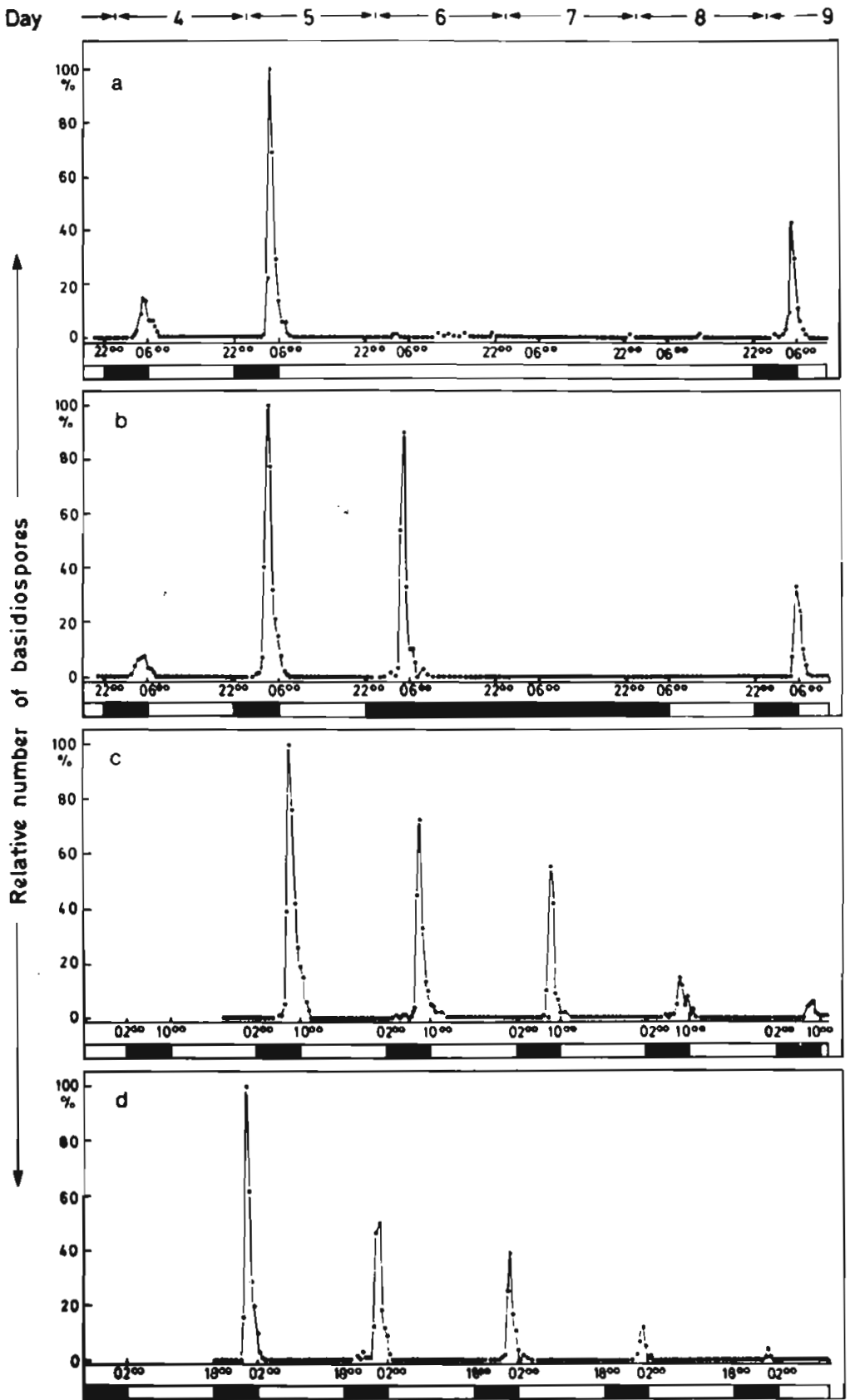

Time of day

Fig. 4. Effect of continuous light (a) and dark (b) and temporal position (c--d) of a long-day photoperiod on basidiospore release. In (a) and (b), teliospores were first incubated under long-day conditions until the maximum peak appeared, then under continuous light or dark, and finally $1 \mathrm{~d}$ under a long-day photoperiod. In (c) and (d), the temporal position of the long-day photoperiod was shifted $4 \mathrm{~h}$, plus or minus, respectively. Spore age: $\sim 36$ mo 
Following conditioning with a long-day photoperiod until the maximum peak arose, spores were incubated in continuous light (Fig. 4 a) or continuous dark (Fig. 4 b). Both conditions resulted in total inhibition of teliospore germination and basidiospore release, but on return to the original alternating light and dark conditions, the periodic pattern was immediately reestablished (Fig. 4 a-b, see days 8-9).

The timing of basidiospore release was dictated by the length and position of the photoperiod. The peak maxima, as averaged through all experiments ( $=58$ samples), occurred $\sim 7.0 \pm 0.7 \mathrm{~h}$ after each respective light off signal. A $4 \mathrm{~h}$ shift in the long-day photoperiod, either plus or minus, induced a corresponding shift in the timing of basidiospore liberation (Fig. $4 \mathrm{c}$ and d).

Preliminary experiments have shown that a daily periodicity with 3 distinct peak maxima can be induced by subjecting teliospores to three 4-hour photoperiods alternating with 3 equivalent dark periods. Under these conditions spore release increased rapidly to a peak in each dark period, $7-8 \mathrm{~h}$ after light was off.
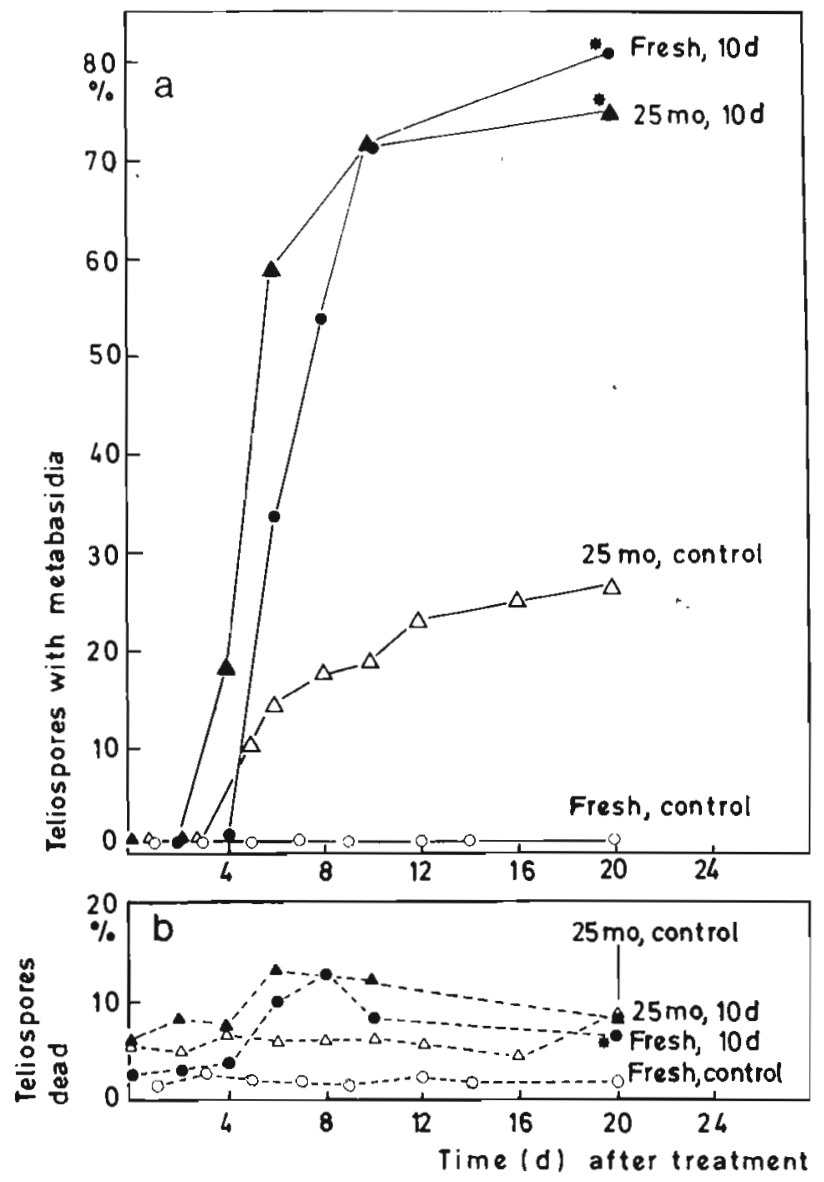

Fig. 5. Rate of germination (a) and mortality (b) of fresh versus stored $\left(4^{\circ} \mathrm{C}\right)$ teliospores of SWBR after treatment with seedling volatiles or no treatment (controls) 


\section{Influence of host volatiles on teliospore germination}

A $10 \mathrm{~d}$ exposure of teliospores to bean seedlings resulted in high percentages of germination (70-80\%) as compared to nonexposed controls at 15-20 d after the treatment (Fig. 5 a). No differences were detected between fresh and stored spores. Identical to the pattern observed in the heat treatment experiments (GOLD and MENDGEN $1983 \mathrm{a}$ ), germination increased at 3-5 d after the treatment or plating of the controls, respectively. Likewise, the seedlings treatment also caused a small increase in spore mortality in most cases (Fig. 5 b).

Infection trials with seedling-treated teliospores were highly successful yielding consistently heavy basidiospore infections. Seedlings from 3 different susceptible varieties (cvs. Favorit, Golden Gate Wax, and 017) were all effective in stimulating germination.

The length of the treatment with seedlings played a critical role in the relative amount of germination and mortality that resulted from the activation process. Only spores treated with volatile substances from bean seedlings for 8,10 , or $12 \mathrm{~d}$ showed a significant increase over the controls (Fig. 6 a).

The relative efficiency of treatment with the seedlings was not identical with the 4 different bean rust isolates tested. Whereas exceptionally high levels of germination could be activated with SWBR (up to $85 \%$ ), the isolates
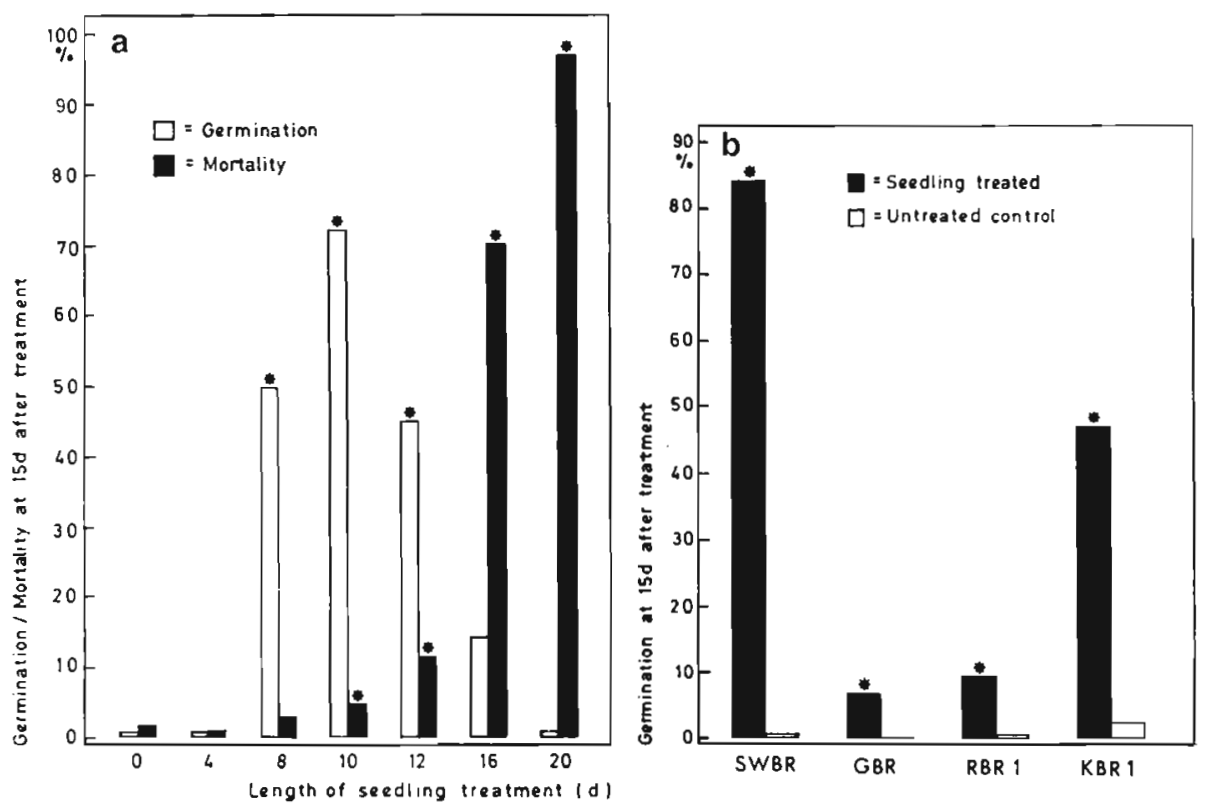

Fig. 6. (a) Rate of germination and mortality of SWBR teliospores as a function of seedling treatment duration. Spore age: $2.5 \mathrm{mo}$; (b) Rate of teliospore germination as a function of spore isolate. Spores were treated with seedling volatiles for $10 \mathrm{~d}$ or not treated (controls). Spore age: $8.5,14,6,13.5$ mo for SWBR, GBR, RBR 1, KBR 1, respectively 
KBR 1, RBR 1, and GBR responded markedly weaker with average values of 47,9 , and $7 \%$ germination, respectively, at $15 \mathrm{~d}$ after treatment (Fig. $6 \mathrm{~b}$ ). On the other hand, if each isolate is viewed singly, then it is apparent that the seedling treatment induced in all isolates a significant increase in germination over the controls.

The treatment with the seedlings did not affect the teliospores' requirement for light to germinate. Continous incubation in the dark resulted in a minimal amount $(<1 \%)$ of germination and a relatively high mortality rate $(\sim 39 \%)$ compared to control spores. Subsequent light exposure $(16 \mathrm{~h} / \mathrm{d})$ of the dark incubated controls and treated spores resulted in rapid increase in germination which reached the level of light incubated samples within $1-3 \mathrm{~d}$.

A combined activation treatment using heat $\left(31.6^{\circ} \mathrm{C}, 3 \mathrm{~d}\right)$ followed by seedlings $(10 \mathrm{~d})$ induced a similar amount of germination as did the treatment with the seedlings alone, but killed more spores $(\sim 43 \%)$ than usual. The reverse combination resulted in $100 \%$ mortality of the spore population.

Although light was not required during the length of the heat or seedling treatments, a light-dark alternation was necessary for the germination process during the post treatment period.

\section{Influence of heat and seedling treatments on teliospore germination of selected rust species}

Teliospore germination of the 6 tested rusts was not markedly affected by either the heat or bean seedling treatments (Table 1). Small increases after heat treatment were observed in $P$. sorghi and $U$. dianthi, however, concomitant with a high level of variation. Whereas spore mortality was not relevantly affected by the seedling treatment, heat caused significant increases of spore death in $P$. mucronatum, $P$. violaceum, and $U$. dianthi. The isolate $U$. scuttelatus was neither positively nor negatively influenced by the heat or treatment with seedlings.

Table 1

Germination and mortality of teliospores from six unrelated rust species after treatment with heat, bean seedlings or no treatment

\begin{tabular}{|c|c|c|c|c|c|c|}
\hline \multirow{3}{*}{ Isolate } & \multicolumn{6}{|c|}{$\%$ Germination and Mortality at $15 \mathrm{~d}$ after treatment } \\
\hline & \multicolumn{2}{|c|}{ control } & \multicolumn{2}{|c|}{$32^{\circ}, 4 \mathrm{~d}$} & \multicolumn{2}{|c|}{$\begin{array}{c}\text { bean volatiles } \\
10 \mathrm{~d}\end{array}$} \\
\hline & germ. & mort. & germ. & mort. & germ. & mort. \\
\hline P. mucronatum & 0 & 2.1 & 0 & 30.1 & 0 & 4.8 \\
\hline P. violaceum & 0 & 18.4 & 0 & 92.4 & 0 & 22.7 \\
\hline P. càrthami & 2.7 & 4.1 & - & - & 0.2 & 7.7 \\
\hline P. sorghi & 1.4 & 9.4 & 5.3 & 11.5 & 0.7 & 3.5 \\
\hline$U$. dianthi & 30.4 & 28.7 & 40.1 & 44.4 & 一 & - \\
\hline U.scuttelatus & 0.1 & 4.1 & 0 & 3.7 & 0 & 4.3 \\
\hline
\end{tabular}




\section{Discussion}

\section{Effect of light}

The requirement of light, dark or alternating periods of light and dark (= light-dark) has been investigated with teliospores of several species (LAMBERT 1929). More recent studies have shown that rust teliospores may (1) germinate equally well in continuous light or dark (BEGA 1959, PADY and CraMER 1971), (2) germinate normally in continuous dark but are inhibited in light (JACOBI et al. 1982, SATO et al. 1980, YAMADA 1956), or (3) germinate normally in light-dark but a) not in continuous dark (NeUHAUs 1969) or b) greatly reduced in continuous light (RAGAzZr and FerrinI 1978). The teliospores of bean rust fall into the third group as germination only occurs in light-dark. Neunaus (1969) reported that a single light exposure of 1000$1500 \mathrm{~lx}$ for $1 \mathrm{~min}$ was sufficient to induce germination in a teliospore population that had been incubated prior and after the light exposure to continuous dark. In bean rust $15 \mathrm{~lx}$ for $16 \mathrm{~h} / \mathrm{d}$ was sufficient to allow normal teliospore germination.

Rhythmic germination could be induced to occur at any time of day or night by an appropriate periodicity of the light-dark regime. This was evidenced by the $\pm 4 \mathrm{~h}$ shift in the position of peak maxima in direct relation to the shift of the long-day photoperiod, and the multiple photoperiod experiment in which three peak maxima/day were induced on 5 consecutive days. It is important to note that the peak maxima in the latter experiment appeared as usual $\sim 6-8 \mathrm{~h}$ after light was out. This is significant because the peak maxima were forced to appear in the light phases due to the short dark periods. These observations demonstrate clearly that light per se does not inhibit the basidiospore release process. In this respect bean rust differs from G. juniperi-virginianae and Gymnosporangium clavipes (PADY and KRAMER 1971 ) in which peak maxima only arose in the dark phase of light-dark cycles.

It should be emphasized that the dosage of light did not significantly influence the periodicity of teliospore germination. Rather, it was the temporal position of the light phase that controlled rhythmic germination. The phase change light $\rightarrow$ dark signaled the start of the germination process each day. A similar relationship was observed with teliospores of P. sorghi (Neunaus 1969).

Recent research on urediniospore and teliospore germination suggest that a photoreceptor system may exist in rust and smut spores (LuCAs et al. 1975, Schauz 1968, 1977, Schneider and Murray 1979). Similar to the photochrome system in higher plants this photoreceptor could be activated by light and in its activated form then serve as a catylst or initiating factor in the germination process.

\section{Effect of host volatiles}

Kuisiewicz $(1972,1973)$ and Binder et al. (1977) demonstrated that volatile substances from safflower, especially from seedlings, greatly stimulated the germination of dormant teliospores of $P$. carthami. Several volatile 
stimulants from safflower seedlings were isolated and identified. They were all found to be $C_{13}$ polyacetylenic hydrocarbons (BINDER et al. 1977). Volatiles from germinating bean seeds were also effective in stimulating the germination of dormant teliospores in $U$. appendiculatus var. appendiculatus. However, an overexposure with bean volatiles led to an increase in spore mortality and abnormal germination. Although gas chromatographic analyses have shown that ethylene is present in relatively high concentrations in the seedling treatment chambers $(\sim 20 \mathrm{ppm})$ it is not responsible for activation (Gold 1983).

A combined heat/seedling treatment did not significantly increase the level of germination and a higher level of mortality was also recorded. KLISIEWICZ (1977) reported a similar response in P. carthami. Basidiospore inoculations with seedling-treated teliospores resulted in abundant infections with normal, fertile pycnia. Basidiospore inoculations with heat/seedling treated teliospores resulted in little infection although a high percentage of teliospores were scored for germination. These experiments indicate that the basidiospore dispersal mechanism was irreparably damaged by the initial heat treatment. The influence of host volatiles on the virulence of basidiospores is unknown.

The activation methods developed for bean rust teliospores were either ineffective or injurious to the teliospores of the six tested different species. The treatments with volatiles from germinating bean seeds demonstrated that those substances do not exhibit general stimulatory properties; rather, they specifically activate certain isolates of bean rust. KLIsIEwICZ (1972) showed that extracts from non-host plants weakly stimulate teliospore germination of safflower rust. Preliminary experiments on the effect of volatiles from corn and wheat seedlings on bean rust teliospores showed no activation.

We gratefully acknowledge the technical assistance of Miss G. GerLACH and Mrs. E. Dressler. Thanks also go to Prof. L. J. Littlefield for reading the manuscript, Mr. F. MeinHARDT for preparation of the graphic representations and Drs. A. ElepFandT and G. EhreT for advice on statistical analysis. R.E.G. is indebted to Dr. A. ToEpfer for providing an Alexander von Humboldt Scholarship during initial stages of this work.

\section{Literature}

BEGA, R. V., 1959: The capacity and period of maximum production of sporidia in Cronartium ribicola. Phytopathology 49, 54-57.

Binder, R. G., J. M. Klisiewicz, and A. C. Waiss, Jr., 1977: Stimulation of germination of Puccinia carthami teliospores by polyacetylenes from safflower. Phytopathology 67, 472-474.

GolD, R. E., 1983: Activation and pattern of teliospore germination in Uromyces appendiculatus var. appendiculatus and basidiospores infection of Phaseolus vulgaris. Universität Konstanz, Dissertation.

- - , and K. Mendgen, 1983a: Activation of teliospore germination in Uromyces appendiculatus var. appendiculatus. I. Aging and temperature. Phytopath. Z. (in press).

- - and - -, 1983b: Cytology of teliospore germination and basidiospore formation in Uromyces appendiculatus var. appendiculatus. Protoplasma (in press). 
JACOBI, W. R., H. V. AMERson, and R. L. MOTT, 1982: Microscopy of cultured loblolly pine seedlings and callus inoculated with Cronartium fusiforme. Phytopathology 72, $138-143$.

KLISIEWiCZ, J. M., 1972: Effect of host plant materials and temperature on germination of teliospores of Puccinia carthami. Phytopathology 62, 436-438.

- -, 1973: Effect of volatile substances from safflower on germination of teliospores of Puccinia carthami. Phytopathology 63, 795.

- - 1977: Effect of flooding and temperature on incidence and severity of safflower seedling rust and viability of Puccinia carthami teliospores. Phytopathology 67, 787-790.

LAMBert, E. B., 1929: The relation of weather to the development of stem rust in the Mississippi Valley. Phytopathology $19,1-71$.

Lucas, J. A., R. E. Kendrick, and C. V. Givan, 1975: Photocontrol of fungal spore germination. Plant Physiol. 56, 847-849.

Mendgen, K., 1983: Development and physiology of teliospores. In: Roenfs, A. P., and W. R. Bushnell (Eds.), The Cereal Rusts (in press). Academic Press, New York.

Neuhaus, W., 1969: Zur Teleutosporenkeimung von Puccinia sorgbi Schw. Zbl. Bakt. II. Abt. $123,266-271$.

Pady, S. M., and C. L. Kramer, 1971: Basidiospore discharge in Gymnosporangium. Phytopathology 61, 951-953.

RaGazZI, A., and F.,Ferrini, 1978: Indagine sulla fertilità e sulla sporulazione dei teleutoconidi di Cronartium flaccidum (Alb. et Schw.) Wint. Phytopath. Medit. 17, 120-126.

Sato, T., K. Katsuya, and S. Sato, 1980: Host range, teliospore germination and infection process of Uromyces aloes. Trans. Mycol. Soc. Jpn. 21, 273-282.

Schauz, K., 1968: Die Steuerung der Bran̉dsporenkeimung und Sporidenbildung bei Tilletia caries (DC) Tul. durch Licht. Arch. Mikrobiol. 60, 111-123.

- -, 1977: Die Promyzel- und Sporidienbildung beim Zwergsteinbrand - Tilletia controversa (Kühn) - in Abhängigkeit von der Lichtquantität und -qualität. Phytopath. Z. $89,135-145$.

Schneider, M. J., and B. J. Murray, 1979: Phytochrome mediation of uredospore germination in the fungus Puccinia graminis. Photochem. Photobiol. 29, 1051-1052.

Sibilia, C., 1931: Ricerche sulla ruggini dei cereali. III. La germinazione della teleutospore di Puccinia coronifera, P.triticina, e P.graminis. Boll. R. Staz. Patol. Veg. 11, 115-128.

YAMADA, S., 1956: Experiments on the epidemiology and control of chrysanthemum white rust, caused by Puccinia boriana P. Henn. Ann. Phytopathol. Soc. Jpn. 20, 148-154.

Authors' address: R. E. Gold, and K. Mendagen, Lehrstuhl für Phytopathologie, Universität Konstanz, D-7750 Konstanz (F. R. Germany). Present address of senior author: Department of Plant Pathology, Cornell University, Ithaca, NY 14853 (USA). 